\title{
Relationship of serum IgE concentration to level and rate of decline of pulmonary function: the Normative Aging Study
}

\author{
Nancy A Shadick, David Sparrow, George T O’Connor, Deborah DeMolles, Scott T Weiss
}

Normative Aging

Study,

Department of

Veterans Affairs

Outpatient Clinic

D Sparrow

Channing Laboratory $S$ T Weiss

\section{Department of Medicine \\ D De Molles \\ $S$ T Weiss}

Department of Rheumatology

N A Shadick

Brigham and Women's Hospital

Pulmonary and Critical Care Division, Beth Israel Hospital $S$ T Weiss

Harvard Medical

School

N A Shadick

$S \mathrm{~T}$ Weiss

Pulmonary Center, Department of

Medicine,

Boston University

School of Medicine

G T O'Connor

Boston,

Massachusetts,

Reprint requests to:

Dr D Sparrow, Veterans

Dr D Sparrow, Veterans

251 Causeway Street,

251 Causeway Street,

02114, USA.

Received 27 September 1995

Returned to authors

5 December 1995

Revised version received

6 March 1996

Accepted for publication

11 March 1996

\begin{abstract}
Background - Previous reports on the relationship between serum immunoglobulin $E$ (IgE) concentration and the level and rate of decline of pulmonary function in the general population have produced conflicting results. The relationship between total serum IgE concentration and pulmonary function was therefore examined in 1078 men aged 41-86 years followed in the Normative Aging Study.
\end{abstract}

Methods - The serum IgE concentration determined at the start of the three year follow up period was examined in relation to both the level and longitudinal rate of decline of forced expiratory volume in one second $\left(F E V_{1}\right)$, forced vital capacity (FVC), and FEV 1 /FVC.

Results - In a cross sectional analysis restricted to subjects who had ever smoked cigarettes, multiple linear regression models indicated an inverse association between total serum IgE concentration and both FEV $_{1}(\beta=-0.090$ $1 / \log _{10}$ IU $/ \mathrm{ml} ;$ SE $\left.=0.030 ; p<0.005\right)$ and FVC $^{10}\left(\beta=-0.1101 / \log _{10}\right.$ IU/ml; SE = 0.034; p < 0.005) but not FEV $/$ FVC, after adjustment for age and height. This relationship persisted when individuals with diagnosed asthma or methacholine hyperresponsiveness were excluded. In subjects who had never smoked cigarettes the total serum IgE concentration was unrelated to spirometric indices. No association was observed in smokers or non-smokers between the serum IgE concentration measured at the beginning of the period of follow up and the decline in $\mathrm{FEV}_{1}, \mathrm{FVC}$, or FEV 1 /FVC.

Conclusion - Increased levels of serum IgE measured at the beginning of the follow up period are associated with lower levels of pulmonary function but are not predictive of an accelerated rate in the decline of pulmonary function among middle aged and older men.

(Thorax 1996;51:787-792)

Keywords: IgE, spirometry, smoking.

The importance of immunoglobulin $\mathrm{E}$ (IgE) in the pathophysiology of asthma, ${ }^{1}$ and the development of irreversible airflow obstruction in some subjects with asthma, ${ }^{2}$ suggest that $\operatorname{IgE}$ may play a part in the pathogenesis of chronic (irreversible) airflow obstruction. IgE medi- ated allergy to environmental aeroallergens causes eosinophilic inflammation of the small airways. ${ }^{3}$ In the short term this inflammation is associated with reversible airflow obstruction and increased airway responsiveness. ${ }^{45}$ If sustained for long periods of time, this inflammation may lead to the development of chronic irreversible airflow obstruction. Population studies of serum total IgE concentration and lung function have produced inconsistent findings. In several cross sectional studies spirometric indices were inversely related to serum total $\operatorname{IgE}$ concentration in occupational and clinic based samples. ${ }^{6-8}$ In two of these studies $^{68}$ this relationship was present even when the analysis was restricted to subjects without asthma. In contrast, Burrows and coworkers $^{9}$ observed that the serum IgE concentration and forced expiratory volume in one second $\left(\mathrm{FEV}_{1}\right)$ were not significantly related when subjects with asthma were excluded from the analysis. Several longitudinal studies have revealed no significant relationship between the rate of decline of $\mathrm{FEV}_{1}$ and the serum total IgE concentration. ${ }^{7} 1011$ Two longitudinal studies did show a significant direct relationship between the IgE concentration and the rate of decline of $\mathrm{FEV}_{1}$; however, in one of these studies ${ }^{8}$ this relationship was only seen in never and former smokers while in the other study ${ }^{12}$ it was present only among current smokers.

We examined the level and the rate of decline of ventilatory function in relation to the serum total IgE concentration measured at the beginning of a three year follow up period in 1078 middle aged and older men. These relationships were assessed in the total sample and within subgroups defined by smoking status in view of the suggestion that they may differ between smokers and non-smokers.

\section{Methods}

POPULATION

The Normative Aging Study is a longitudinal study of aging established by the Veterans Administration in $1961 .^{13}$ The study cohort initially consisted of 2280 community dwelling men from the greater Boston area who were aged 21-80 years on enrollment into the study. Volunteers were screened before entry according to specific health criteria ${ }^{13}$ and were accepted into the study only if they were free of known chronic medical conditions. In particular, volunteers with asthma, chronic bronchitis, or chronic sinusitis were excluded.

Since entry the men have reported for periodic examinations, each consisting of a 
uniform medical history and physical examination in addition to blood and urine tests. Since 1984 subjects have also completed a detailed symptom and smoking questionnaire and have undergone methacholine challenge testing, allergy skin testing, and serum $\operatorname{IgE}$ measurement at each examination. Subjects are instructed to refrain from eating and drinking after midnight and to refrain from smoking after 20.00 hours on the night before each examination. The protocol for this study was approved by the human studies subcommittee of the research and development committee, Department of Veterans Affairs Outpatient Clinic and written informed consent was obtained from all subjects.

QUESTIONNAIRE DATA

Standard questionnaires based on the American Thoracic Society DLD-78 questionnaire ${ }^{14}$ were used to obtain information on respiratory symptoms and illness as well as smoking habits. Current smokers were defined as those men who had smoked at least one cigarette per day for at least the past year and were still smoking at least one month before the examination. Former smokers were defined as those men who had previously smoked at least one cigarette per day for at least one year but who had ceased smoking more than one month before the examination. Never smokers were defined as those men who had never smoked cigarettes or smoked fewer than a total of 20 packs during their lifetime.

SPIROMETRIC TESTS

Subjects performed forced vital capacity manoeuvres in the standing position with noseclips. An eight litre water-filled spirometer with microprocessor (Eagle II, Warren E Collins Inc, Braintree, Massachusetts, USA) was used to measure forced vital capacity (FVC) and $\mathrm{FEV}_{1}$, which was corrected to BTPS. A minimum of three acceptable manoeuvres were performed unless this could not be accomplished after eight attempts. Additional manoeuvres were performed, up to a maximum of eight, until the two highest values of both FVC and $\mathrm{FEV}_{1}$ were reproduced within $5 \%$. The highest values of $\mathrm{FVC}$ and $\mathrm{FEV}_{1}$ were used for analysis. The $\mathrm{FEV}_{1} / \mathrm{FVC}$ ratio from the spirogram with the highest sum of FVC plus $\mathrm{FEV}_{1}$ was used for analysis. Predicted values for $\mathrm{FEV}_{1}$, FVC, and $\mathrm{FEV}_{1} / \mathrm{FVC}$ ratio were derived from regressions of these measurements on age and height among 250 asymptomatic never smokers in the Normative Aging Study cohort.

METHACHOLINE CHALLENGE PROTOCOL Subjects underwent a methacholine challenge protocol adapted from that of Chatham and coworkers. ${ }^{15}$ Saline and methacholine solutions were aerosolised with a DeVilbiss 646 nebuliser attached to a DeVilbiss air compressor (DeVilbiss, Somerset, Pennsylvania, USA). All inhalations were six second inspiratory manoeuvres from residual volume to total lung capacity followed by two seconds breath holding. Incremental doses of methacholine were inhaled at five minute intervals according to the following schedule: five inhalations of 0 $\mathrm{mg} / \mathrm{ml}$ (phenol buffered saline alone), one inhalation of $1 \mathrm{mg} / \mathrm{ml}$, one inhalation of 5 $\mathrm{mg} / \mathrm{ml}$, four inhalations of $5 \mathrm{mg} / \mathrm{ml}$, one inhalation of $25 \mathrm{mg} / \mathrm{ml}$, and four inhalations of $25 \mathrm{mg} / \mathrm{ml}$. Determination of nebuliser output by weight ${ }^{16}$ indicated that the methacholine inhalation schedule corresponded to the following cumulative doses of methacholine in $\mu$ mol: $0,0.33,1.98,8.58,16.80$, and 49.80 . Spirometric tests were performed 30, 90, and 180 seconds after each inhalation level. If the first two spirograms at each level were consistent $\left(\mathrm{FEV}_{1}\right.$ within $\left.5 \%\right)$, then the higher $\mathrm{FEV}_{1}$ of these two was chosen for analysis. Otherwise, the higher $\mathrm{FEV}_{1}$ from the most consistent pair of acceptable spirograms was used. The test was terminated when a $20 \%$ decline in $\mathrm{FEV}_{1}$ from the post-saline value occurred or at the end of the dose schedule if such a decline did not occur.

SERUM TOTAL IGE CONCENTRATION

Serum total IgE was determined by paper radioimmunosorbent test (Pharmacia Diagnostics, Piscataway, New Jersey, USA). The mean of two determinations on each serum specimen was used for analysis.

STUDY SAMPLE

The subjects in the current study were a subgroup of the Normative Aging Study cohort. Between 1984 and 1992, 1489 men reported for at least one examination. Of these, 1192 reported twice during this period and were therefore eligible for inclusion in this longitudinal analysis. A total of 114 subjects were excluded from analysis because of incomplete information on serum total IgE concentration or other independent variables of interest. Thus, 1078 subjects with complete data were available for analysis.

DATA ANALYSIS

Pulmonary function (FVC, $\mathrm{FEV}_{1}$, and $\mathrm{FEV}_{1}$ / FVC) was measured at two consecutive visits three years apart. The first of the two visits was used for cross sectional analyses and the annual change between the two visits was used for longitudinal analyses. Serum IgE concentration at the first visit was analysed as a continuous and categorical variable (quartile). The subjects were categorised into four groups defined by the quartile ranges of IgE concentration in current smokers. When used as a continuous variable, the serum IgE concentration was logarithmically transformed $\left(\log _{10}\right)$ before statistical analysis because of its approximately log normal distribution.

For selected analyses, subjects were excluded if, at either of the two visits, they had either or both of the following conditions: (1) diagnosed asthma, defined as having a positive response to the question: "Have you ever received a diagnosis of asthma from a doctor?" or (2) hyperresponsiveness to methacholine, defined as $\geqslant 20 \%$ decline in $\mathrm{FEV}_{1}$ (from post-saline value) at or before four inhalations of $5 \mathrm{mg}$ methacholine $/ \mathrm{ml}$ (cumulative dose $8.58 \mu \mathrm{mol}$ ). 
Table 1 Characteristics of 1078 male participants in the Normative Aging Study with available data on serum IgE concentration and spirometric parameters

\begin{tabular}{|c|c|c|}
\hline Mean (range) age (years) & \multirow{2}{*}{\multicolumn{2}{|c|}{$\begin{array}{l}60(41-86) \\
\quad 1.5(0.02)\end{array}$}} \\
\hline Mean (SE) $\log _{10}$ IgE $(\log \mathrm{IU} / \mathrm{ml})$ & & \\
\hline \multicolumn{3}{|l|}{ Smoking status (no (\%)) } \\
\hline Current & 145 & (13) \\
\hline Former & 590 & (55) \\
\hline Never & 343 & (32) \\
\hline \multicolumn{3}{|l|}{ Asthma (no (\%)) } \\
\hline Current & 16 & (1) \\
\hline In past & 30 & (3) \\
\hline Never & 1031 & (96) \\
\hline Missing data & 1 & \\
\hline \multicolumn{3}{|l|}{ Hay fever (no (\%)) } \\
\hline Yes & 213 & (20) \\
\hline No & 862 & (80) \\
\hline Missing data & 3 & \\
\hline \multicolumn{3}{|l|}{ Any wheeze (no (\%)) } \\
\hline Yes & 154 & (14) \\
\hline No & 922 & (86) \\
\hline Missing data & 2 & \\
\hline Mean (SE) FVC (\% predicted) ${ }^{\star}$ & 96 & $(0.5)$ \\
\hline Mean $(\mathrm{SE}) \mathrm{FEV}_{1}(\% \text { predicted })^{\star}$ & 93 & $(0.5)$ \\
\hline
\end{tabular}

Analysis of covariance and multiple linear regression were performed with the SAS statistical software package (SAS Institute Inc, Cary, North Carolina, USA).

\section{Results}

CROSS SECTIONAL RESULTS

Characteristics of the study sample are given in table 1. Mean levels of pulmonary function, adjusted for age and height, according to serum IgE and smoking status are presented in table 2. Mean levels of $\mathrm{FEV}_{1}, \mathrm{FVC}$, and $\mathrm{FEV}_{1}$ /
FVC were highest in never smokers and lowest in current smokers. The mean $\mathrm{FEV}_{1} / \mathrm{FVC}$ ratio showed no apparent trend across quartiles of IgE in any group. In former and current smokers there was a suggestion of lower mean levels of $\mathrm{FEV}_{1}$ and FVC in the higher IgE quartiles. Adjustments for smoking exposure using pack years, cigarettes currently smoked per day, and both smoking exposure measures together did not change the results (data not shown).

Analyses run on a subsample of 907 subjects, excluding those with diagnosed asthma and those with hyperresponsiveness to methacholine (as defined in the Methods section) showed similar results (table 3). Different cut off points for IgE as chosen by Dow et al $(\leqslant 10,11-30,31-80,>80 \mathrm{U} / \mathrm{ml})$ were also considered in combination with smoking status. The adjusted means for all three pulmonary function measures did not change substantially (data not shown).

Multiple linear regression was used to assess the statistical significance of the relationship between $\log _{10}$ IgE concentrations and levels of pulmonary function in three models adjusting for age, height, and smoking status. In all 1078 subjects smoking status was significantly related to level of $\mathrm{FEV}_{1} / \mathrm{FVC}$ (table 4). No relationship was observed between $\mathrm{FEV}_{1} / \mathrm{FVC}$ and $\log _{10}$ IgE. $\mathrm{FEV}_{1}$ also was significantly related to smoking status but, in addition, was significantly related inversely to $\log _{10} \operatorname{IgE~(p~}$ $<0.05$ ). Similarly, FVC showed a significant inverse relationship to $\log _{10} \operatorname{IgE}(p<0.05$ ). The multiple linear regression analyses were repeated after the sample was restricted to the 907 subjects without diagnosed asthma or

Table 2 Adjustedt mean levels of pulmonary function by smoking status and IgE quartile $(n=1078)$

\begin{tabular}{|c|c|c|c|c|c|c|c|c|}
\hline \multirow{2}{*}{$\begin{array}{l}\text { Smoking } \\
\text { status }\end{array}$} & \multirow{2}{*}{$\begin{array}{l}\text { Quartile of } \\
\text { IgE (U/ml) }\end{array}$} & \multirow[b]{2}{*}{$n$} & \multicolumn{2}{|c|}{$F E V_{1} / F V C(\%)$} & \multicolumn{2}{|c|}{$F E V_{1}(l)$} & \multicolumn{2}{|c|}{$F V C(l)$} \\
\hline & & & Mean & $S E$ & Mean & $S E$ & Mean & $S E$ \\
\hline \multirow[t]{4}{*}{ Never } & $0-16.5$ & 125 & 80.50 & 0.63 & 3.33 & 0.045 & 4.15 & 0.053 \\
\hline & $16.5-51.55$ & 103 & 79.87 & 0.70 & 3.31 & 0.050 & 4.16 & 0.058 \\
\hline & $51.55-141.5$ & 66 & 79.87 & 0.87 & 3.40 & 0.062 & 4.30 & 0.072 \\
\hline & $144.5+$ & 49 & 80.07 & 1.01 & 3.30 & 0.073 & 4.11 & 0.084 \\
\hline \multirow{4}{*}{ Former } & $0-16.5$ & 211 & 77.95 & 0.48 & 3.18 & 0.035 & 4.09 & 0.040 \\
\hline & $16.5-51.55$ & 166 & 78.86 & 0.54 & 3.21 & 0.039 & 4.07 & 0.045 \\
\hline & $51.55-144.5$ & 114 & 79.27 & 0.66 & 3.20 & 0.047 & 4.04 & 0.055 \\
\hline & $144.5+$ & 99 & 77.57 & 0.71 & 3.01 & 0.051 & 3.88 & 0.059 \\
\hline \multirow[t]{4}{*}{ Current } & $0-16.5$ & 36 & 74.16 & 1.18 & 2.95 & 0.085 & 3.98 & 0.099 \\
\hline & $16.5-51.55$ & 35 & 74.11 & 1.19 & 2.88 & 0.086 & 3.89 & 0.100 \\
\hline & $51.55-144.5$ & 38 & 72.30 & 1.15 & 2.65 & 0.083 & 3.66 & 0.096 \\
\hline & $144.5+$ & 36 & 73.24 & 1.18 & 2.78 & 0.085 & 3.76 & 0.098 \\
\hline
\end{tabular}

† Values are adjusted for age and height by analysis of covariance.

Table 3 Adjusted mean levels of pulmonary function by smoking status and IgE quartile excluding subjects with diagnosed asthma or hyperresponsiveness to methacholine $(n=907)$

\begin{tabular}{|c|c|c|c|c|c|c|c|c|}
\hline \multirow{2}{*}{$\begin{array}{l}\text { Smoking } \\
\text { status }\end{array}$} & \multirow{2}{*}{$\begin{array}{l}\text { Quartile of IgE } \\
\text { (U/ml) }\end{array}$} & \multirow[b]{2}{*}{$n$} & \multicolumn{2}{|c|}{$F E V_{1} / F V C(\%)$} & \multicolumn{2}{|c|}{$F E V_{1}$ (l) } & \multicolumn{2}{|c|}{$F V C(l)$} \\
\hline & & & Mean & $S E$ & Mean & $S E$ & Mean & $S E$ \\
\hline \multirow[t]{4}{*}{ Never } & $0-16.5$ & 117 & 80.77 & 0.60 & 3.36 & 0.045 & 4.18 & 0.054 \\
\hline & $16.5-51.55$ & 91 & 80.54 & 0.68 & 3.34 & 0.051 & 4.16 & 0.061 \\
\hline & $51.55-144.5$ & 53 & 79.72 & 0.89 & 3.45 & 0.067 & 4.37 & 0.080 \\
\hline & $144.5+$ & 34 & 82.25 & 1.11 & 3.43 & 0.083 & 4.17 & 0.099 \\
\hline \multirow[t]{4}{*}{ Former } & $0-16.5$ & 184 & 78.75 & 0.48 & 3.25 & 0.036 & 4.14 & 0.043 \\
\hline & $16.5-51.55$ & 143 & 79.32 & 0.54 & 3.26 & 0.041 & 4.12 & 0.049 \\
\hline & $51.55-144.5$ & 91 & 80.91 & 0.68 & 3.31 & 0.051 & 4.09 & 0.061 \\
\hline & $144.5+$ & 82 & 79.38 & 0.72 & 3.08 & 0.054 & 3.90 & 0.064 \\
\hline \multirow[t]{4}{*}{ Current } & $0-16.5$ & 31 & 76.23 & 1.17 & 3.04 & 0.088 & 3.99 & 0.105 \\
\hline & $16.5-51.55$ & 29 & 75.26 & 1.21 & 2.95 & 0.090 & 3.92 & 0.108 \\
\hline & $51.55-144.5$ & 25 & 72.26 & 1.31 & 2.67 & 0.097 & 3.68 & 0.117 \\
\hline & $144.5+$ & 27 & 72.81 & 1.25 & 2.71 & 0.093 & 3.67 & 0.112 \\
\hline
\end{tabular}

† Values are adjusted for age and height by analysis of covariance. 
Table 4 Results of linear regression models relating level of pulmonary function to selected covariates $(n=1078)$

\begin{tabular}{|c|c|c|c|c|c|c|c|c|c|}
\hline \multirow[b]{2}{*}{$\begin{array}{l}\text { Independent } \\
\text { variable }\end{array}$} & \multicolumn{3}{|c|}{$F E V_{t} / F V C(\%)$} & \multicolumn{3}{|l|}{$F E V_{1}$ (l) } & \multicolumn{3}{|l|}{$F V C(l)$} \\
\hline & $\begin{array}{l}\text { Regression } \\
\text { coefficient }\end{array}$ & $S E$ & $p$ value & $\begin{array}{l}\text { Regression } \\
\text { coefficient }\end{array}$ & $S E$ & $p$ value & $\begin{array}{l}\text { Regression } \\
\text { coefficient }\end{array}$ & $S E$ & $p$ value \\
\hline Age & -0.1927 & 0.0298 & 0.0001 & -0.0340 & 0.0022 & 0.0001 & -0.0338 & 0.0025 & 0.0001 \\
\hline Height & -0.4921 & 0.0866 & 0.0001 & 0.0796 & 0.0063 & 0.0001 & 0.1249 & 0.0073 & 0.0001 \\
\hline \multicolumn{10}{|l|}{ Smoking status } \\
\hline $\begin{array}{l}\text { Current } \\
\text { smokert }\end{array}$ & -6.6135 & 0.7179 & 0.0001 & -0.5063 & 0.0520 & 0.0001 & -0.3342 & 0.0603 & 0.0001 \\
\hline Former smoker $\ddagger$ & -1.7215 & 0.4814 & $<0.0005$ & -0.1672 & 0.0349 & 0.0001 & -0.1333 & 0.0404 & 0.001 \\
\hline $\log _{10} \operatorname{IgE}$ & -0.3196 & 0.3293 & NS & -0.0607 & 0.0239 & $<0.05$ & -0.0664 & 0.0277 & $<0.05$ \\
\hline Constant & 126.0235 & & & 0.0123 & & & -2.2555 & & \\
\hline
\end{tabular}

† Effects are relative to never smokers ( $1=$ current smoker, $0=$ otherwise).

$\ddagger$ Effects are relative to never smokers $(1=$ former smoker, $0=$ otherwise $)$.

Table 5 Adjusted t mean annual change in pulmonary function by smoking status and IgE quartile combinations $(n=1078)$

\begin{tabular}{|c|c|c|c|c|c|c|c|c|}
\hline \multirow{2}{*}{$\begin{array}{l}\text { Smoking } \\
\text { status }\end{array}$} & \multirow{2}{*}{$\begin{array}{l}\text { Quartile of } I g E \\
(U / m l)\end{array}$} & \multirow[b]{2}{*}{$n$} & \multicolumn{2}{|c|}{$\triangle F E V_{1} / F V C(\% /$ year $)$} & \multicolumn{2}{|c|}{$\triangle F E V_{1}$ (ml/year) } & \multicolumn{2}{|c|}{$\Delta F V C$ (mllyear) } \\
\hline & & & Mean & $S E$ & Mean & $S E$ & Mean & $S E$ \\
\hline \multirow[t]{4}{*}{ Never } & $0-16.5$ & 125 & -0.3830 & 0.1068 & -31.36 & 5.77 & -14.37 & 7.98 \\
\hline & $16.5-51.55$ & 103 & -0.3719 & 0.1175 & -34.92 & 6.36 & -21.19 & 8.81 \\
\hline & $51.55-144.5$ & 66 & -0.0363 & 0.1460 & -18.96 & 7.93 & -20.99 & 11.00 \\
\hline & $144.5+$ & 49 & -0.3903 & 0.1697 & -28.22 & 9.17 & -12.17 & 12.72 \\
\hline \multirow[t]{4}{*}{ Former } & $0-16.5$ & 211 & -0.2668 & 0.0816 & -34.72 & 4.41 & -33.59 & 6.13 \\
\hline & $16.5-51.55$ & 166 & -0.5087 & 0.0919 & -37.23 & 4.97 & -21.19 & 6.89 \\
\hline & $51.55-144.5$ & 114 & -0.2823 & 0.1110 & -35.74 & 5.99 & -30.37 & 8.32 \\
\hline & $144.5+$ & 99 & -0.3359 & 0.1193 & -43.27 & 6.48 & -42.96 & 8.99 \\
\hline \multirow[t]{4}{*}{ Current } & $0-16.5$ & 36 & -0.7028 & 0.1994 & -57.60 & 10.75 & -45.08 & 14.89 \\
\hline & $16.5-51.55$ & 35 & -0.5184 & 0.2019 & -46.05 & 10.91 & -40.42 & 15.09 \\
\hline & $51.55-144.5$ & 38 & -0.9826 & 0.1957 & -56.75 & 10.64 & -46.92 & 14.62 \\
\hline & $144.5+$ & 36 & -0.5584 & 0.1993 & -58.48 & 10.79 & -64.57 & 14.90 \\
\hline
\end{tabular}

† Values are adjusted for age and height by analysis of covariance.

methacholine hyperresponsiveness; the results were essentially identical.

Tables 2 and 3 suggested that the relationship of IgE to $\mathrm{FEV}_{1}$ and FVC may be limited to ever smokers, so we repeated the multiple linear regression models predicting $\mathrm{FEV}_{1}$, FVC and $\mathrm{FEV}_{1} / \mathrm{FVC}$ separately for never smokers and ever smokers. Among the 735 ever smokers $\mathrm{FEV}_{1}(\beta=-0.090, \mathrm{SE}=0.030$, $\mathrm{p}<0.005)$ and FVC $(\beta=-0.110$, SE $=$ $0.034, \mathrm{p}<0.005)$ were related to the serum IgE concentration, but $\mathrm{FEV}_{1} / \mathrm{FVC}$ was not $(\beta$ $=-0.247, \mathrm{SE}=0.418, \mathrm{p}=\mathrm{NS})$. Restricting the sample of the 612 ever smokers without diagnosed asthma or methacholine hyperresponsiveness resulted in essentially identical models. No significant relationships were found between $\mathrm{FEV}_{1}, \mathrm{FVC}$, or $\mathrm{FEV}_{1} / \mathrm{FVC}$ and IgE in the 343 never smokers.

We repeated the above regression models among ever smokers, also adjusting for total pack years of smoking. The relationships of serum IgE concentration to $\mathrm{FEV}_{1} \quad(\beta$ $=-0.083, \mathrm{SE}=0.030, \mathrm{p}<0.01), \mathrm{FVC}(\beta=$ $-0.104, \mathrm{SE}=0.034, \mathrm{p}<0.005)$, and $\mathrm{FEV}_{1} / \mathrm{FVC}(\beta=-0.192, \mathrm{SE}=0.417, \mathrm{p}=\mathrm{NS})$ did not change appreciably.

LONGITUDINAL RESULTS

The mean annual changes in pulmonary function, adjusted for age, height, and initial level of pulmonary function, according to initial IgE and smoking status are presented in table 5. For all spirometric indices, never smokers showed the lowest rates of decline and current smokers the highest. No clear relationship between IgE and the rate of decline of pulmonary function was evident within any of the smoking status groups. The analyses in table 5 were repeated after adjustment for age and height only (no adjustment for initial level of pulmonary function) and virtually identical results were obtained (data not shown).

Multiple linear regression models were used to determine the statistical significance of the relationship between $\log _{10}$ IgE and the annual change in pulmonary function variables. After adjustment for age, height, and initial pulmonary function level, $\log _{10}$ IgE was not significantly related to annual change in $\mathrm{FEV}_{1} / \mathrm{FVC}$ $(\beta=-0.019, \mathrm{SE}=0.055, \mathrm{p}=\mathrm{NS}), \mathrm{FEV}_{1}(\beta=$ $-0.693, \mathrm{SE}=2.989, \mathrm{p}=\mathrm{NS})$, or FVC $(\beta=$ $-2.311, \mathrm{SE}=4.151, \mathrm{p}=\mathrm{NS})$. These same analyses performed on the subsample of 907 subjects that excluded asthmatic and hyperresponsive subjects yielded almost identical results (data not shown).

\section{Discussion}

Data from this study demonstrate a significant inverse association between pulmonary function $\left(\mathrm{FEV}_{1}\right.$ and $\mathrm{FVC}$ ) and total serum $\mathrm{IgE}$ concentration in middle aged and older men with a history of smoking. Exclusion of subjects with diagnosed asthma or hyperresponsiveness to methacholine did not appreciably alter these relationships. There was no association between serum IgE concentration and $\mathrm{FEV}_{1} / \mathrm{FVC}$ with adjustment for age, height, and smoking status. Longitudinal analyses revealed that the rates of decline of spirometric indices over a three year follow up period were not correlated with the serum IgE concentration measured at the beginning of the period.

Previous studies that have examined the cross sectional relationship between serum IgE concentration and pulmonary function have 
produced conflicting results. Vollmer et al observed an inverse relationship between serum IgE concentration and level of $\mathrm{FEV}_{1}$ in a cohort of patients in an emphysema screening clinic, but not among randomly selected county employees. Burrows and coworkers ${ }^{9}$ examined the relationship between IgE concentration and $\mathrm{FEV}_{1}$ in 1467 subjects aged 40-74 years who were members of a population based cohort in Tucson, Arizona. A high IgE concentration appeared to be a marker of low $\mathrm{FEV}_{1}$ associated with asthma. No significant relationship was observed in an analysis restricted to subjects who denied a history of asthma. In contrast, Annesi et al observed a significant inverse relationship between serum IgE concentration and $\mathrm{FEV}_{1}$ among both asthmatic and non-asthmatic working men in Paris; this relationship was limited to nonsmokers. Dow et al observed a significant inverse relationship between IgE concentration and $\mathrm{FEV}_{1} / \mathrm{FVC}$ ratio in a sample of elderly men and women, a relationship which persisted when the analysis was restricted to subjects with neither methacholine hyperresponsiveness nor a history of diagnosed asthma. The relationship of $\operatorname{IgE}$ to $\mathrm{FEV}_{1} / \mathrm{FVC}$ ratio was especially strong among current cigarette smokers. Differences in population age, purpose of screening, and method of ascertainment of asthma history may explain the different conclusions of these studies. In the present study the absence of a cross sectional relationship between IgE concentration and the $\mathrm{FEV}_{1}$ / FVC ratio is unexpected if $\operatorname{IgE}$ is related to lung function because of its role in airways disease. The greater intraindividual variability (that is, lower precision) of the $\mathrm{FEV}_{1} / \mathrm{FVC}$ ratio compared with the $\mathrm{FEV}_{1}$ and FVC may partly explain this finding. It remains possible that the observed associations between IgE levels and both $\mathrm{FEV}_{1}$ and FVC are explained by mechanisms other than airways disease.

Despite the cross sectional relationship between the serum IgE concentration and pulmonary function, our study showed no relationship between rate of decline of pulmonary function and serum IgE levels when decline was measured as $\mathrm{FEV}_{1}, \mathrm{FVC}$, and $\mathrm{FEV}_{1} / \mathrm{FVC}$. These results are consistent with the findings of Taylor $e t a l^{10}$ and Vollmer et al who found no relationship between decline in $\mathrm{FEV}_{1}$ and follow up serum IgE levels. In an earlier retrospective analysis of subjects in the Normative Aging Study ${ }^{11}$ a decline in $\mathrm{FEV}_{1}$ was also unrelated to follow up serum IgE levels. In contrast, Annesi and colleagues ${ }^{8}$ demonstrated that a five year decline in $\mathrm{FEV}_{1}$ was related to serum IgE levels at follow up in never smokers and former smokers, but only a weak association remained in former smokers after exclusion of asthmatic subjects and those with positive allergy skin tests.

Most previous studies that have investigated the longitudinal rate of ventilatory decline and serum IgE concentrations have measured total IgE at the end of the follow up period, ${ }^{7}{ }^{1011}$ leaving open the possibility that a high concentration of IgE measured at follow up resulted from, rather than contributed to, pathophysi- ological processes occurring during the follow up period. A recent report by Villar et $a l^{12}$ has provided prospective data which indicate that the serum total IgE concentration predicts the four year decline in $\mathrm{FEV}_{1}$ only in current smokers.

Our observation that the concentration of $\operatorname{IgE}$ is related to the level of lung function but not to the rate of decline of lung function among middle aged and older men has several possible explanations. We have previously reported that non-specific airway responsiveness is directly related to the serum total IgE concentration in this population. ${ }^{17}$ Thus, a high IgE concentration may be associated with increased baseline bronchomotor tone and a reduced level of lung function without being associated with any deterioration in lung function over time. The persistence of the observed relationships after exclusion of asthmatic subjects and those with airway hyperresponsiveness does not eliminate this possibility. Alternatively, IgE-mediated hypersensitivity may have had a deleterious effect on lung function earlier in life - when allergic responses may be more intense ${ }^{18}$ and the lungs are growing - but may have little further impact on lung function by middle age. A high serum IgE concentration may be a marker for early life events, such as passive exposure to environmental tobacco smoke, which led to both impaired lung function ${ }^{1920}$ and the development of allergic sensitisation. ${ }^{21}{ }^{22}$ Finally, the estimates of decline in pulmonary function based on a follow up period of only three years are imprecise ${ }^{23}$ and the "noise" of these estimates may have obscured a relationship between the IgE level and rate of decline of pulmonary function. Furthermore, the small number of current smokers in our sample may have prevented the detection of any effect limited to this group, as suggested by Villar et al. ${ }^{12}$

One possible limitation of this analysis is that the total serum $\operatorname{IgE}$ concentration may lack sensitivity and specificity as a biomarker for the risk of chronic obstructive pulmonary disease. Recent findings that the concentration of $\operatorname{IgE}$ specific for dust mite, a perennial indoor allergen, is predictive of the development of wheezing symptoms ${ }^{24}$ suggest that markers of hypersensitivity to specific allergens may be more useful than total IgE in predicting both symptom development and decline in pulmonary function. In addition, we $\mathrm{e}^{25}$ and Villar et $a l^{12}$ have observed that allergy skin test reactivity is a predictor of decline in pulmonary function, suggesting that serum total IgE and atopy as defined by skin testing are not equivalent with respect to their relationship to the risk of chronic lung disease.

We conclude that increased levels of serum IgE measured at the beginning of the follow up period are associated with lower levels of pulmonary function but are not predictive of an accelerated rate of decline in pulmonary function in middle aged and older men. This relationship remained the same when subjects with diagnosed asthma or hyperresponsiveness were excluded. These findings suggest that a high serum total IgE concentration may not be 
an independent risk factor for a decline of pulmonary function in later life, but may be a marker of increased bronchomotor tone or of processes which adversely affected ventilatory function in earlier life.

This study was supported by grant nos. HL-34645, HL-45089, and SCOR HL-19170 from the Division of Lung Diseases, National Heart, Lung, and Blood Institute, National Institutes of Health; and by the Medical Research and Health Services Research and Development Services of the Department of Veterans Affairs.

1 Burrows B, Martinez FD, Halonen M, Barbee RA, Cline MG. Association of asthma with serum IgE levels and skintest reactivity to allergens. $N$ Engl f Med 1989;320:271-7.

2 Burrows B, Bloom JW, Traver GA, Cline MG. The course and prognosis of different forms of chronic airways obstruction in a sample from the general population. $N$ Engl 7 Med 1987;317:1309-14.

3 Ricci M, Rossi O. Dysregulation of IgE responses and airway allergic inflammation in atopic individuals. Clin Exp Allergy 1990;20:601-9.

4 Durham SR, Kay AB. Eosinophils, bronchial hyperreactivity and late-phase asthmatic reactions. Clin Allergy 1985; and late-pha

5 Taylor KJ, Luksza AR. Peripheral blood eosinophil counts and bronchial responsiveness. Thorax 1987;42:452-6.

6 Dow L, Coggon D, Campbell MJ, Osmond C, Holgate ST. The interaction between immunoglobulin $\mathrm{E}$ and smoking in airflow obstruction in the elderly. Am Rev Respir Dis 1992;146:402-7.

7 Vollmer WM, Buist AS, Johnson LR, McCamant LE, Halonen $M$. Relationship between serum IgE and crosssectional and longitudinal $\mathrm{FEV}_{1}$ in two cohort studies. Chest 1986;90:416-23.

8 Annesi I, Oryszczyn M, Frette C, Neukirch F, Orvoen-Frija $\mathrm{E}, \mathrm{Kauffmann} \mathrm{F}$. Total circulating IgE and $\mathrm{FEV}_{1}$ in adult $\mathrm{E}, \mathrm{Kauffmann} \mathrm{F}$. Total circulating IgE and $\mathrm{FEV}_{1}$ in adult
men: an epidemiologic longitudinal study. Chest 1992; men: an epid

9 Burrows B, Knudson RJ, Cline MG, Lebowitz MD. A reexamination of risk factors for ventilatory impairment. $\mathrm{Am}$ Rev Respir Dis 1988;138:829-36.

10 Taylor RG, Joyce H, Gross E, Holland F, Pride NB. Bronchial reactivity to inhaled histamine and annual rate of decline in FEV ${ }_{1}$ in male smokers and ex-smokers. Thorax 1985;40:9-16.

11 Parker DR, O'Connor GT, Sparrow D, Segal MR, Weiss ST. The relationship of nonspecific airway responsiveness and atopy to the rate of decline of lung function: the Normative Aging Study. Am Rev Respir Dis 1990;141:589-94.
12 Villar MTA, Dow L, Coggon D, Lampe FC, Holgate ST. The influence of increased bronchial responsiveness, atopy, and serum IgE on decline in $\mathrm{FEV}_{1}$. A longitudina study in the elderly. Am $\mathcal{F}$ Respir Crit Care Med 1995;151:656-62.

13 Bell B, Rose CL, Damon H. The Normative Aging Study: an interdisciplinary and longitudinal study of health and aging. Aging Hum Dev 1972;3:5-17.

14 Ferris BG Jr. Epidemiology standardization project. Am Rev Respir Dis 1978;118:1-88.

15 Chatham M, Bleecker ER, Norman P, Smith PL, Mason P. A screening test for airways reactivity: an abbreviated methacholine inhalation challenge. Chest 1982;82:15-18.

16 Sparrow D, O'Connor G, Colton T, Barry CL, Weiss ST The relationship of nonspecific bronchial responsivenes to the occurrence of respiratory symptoms and decreased levels of pulmonary function: the Normative Aging Study. Am Rev Respir Dis 1987;135:1255-60.

17 O'Connor GT, Sparrow D, Segal MR, Weiss ST. Smoking, atopy, and methacholine airway responsiveness among middle-aged and elderly men: the Normative Aging Study. Am Rev Respir Dis 1989;140:1520-6.

18 Barbee RA, Halonen M, Lebowitz MD, Burrows B. Distribution of IgE in a community population sample: correlations with age, sex, and allergen skin test reactivity. $f$ Allergy Clin Immunol 1981;68:106-11.

19 Hanrahan JP, Tager IB, Segal MR, Tosteson TD, Castile $\mathrm{RB}$, Van Vunakis $\mathrm{H}$, et al. The effect of maternal smoking during pregnancy on early infant lung function. $A m$ Rev Respir Dis 1992;145:1129-35.

20 Tager IB, Hanrahan JP, Tosteson TD, Castile RB, Brown $\mathrm{RW}$, Weiss ST, et al. Lung function, pre- and post-natal smoke exposure, and wheezing in the first year of life. $\mathrm{Am}$ Rev Respir Dis 1993;147:811-7.

21 Weiss ST, Tager IB, Munoz A, Speizer FE. The relationship of respiratory infections in early childhood to the occurrence of increased levels of bronchial responsiveness and atopy. Am Rev Respir Dis 1985;131:573-8.

22 Martinez FD, Antognoni G, Macri F, Bonci E, Midulla F DeCastro $\mathrm{G}$, et al. Parental smoking enhances bronchial Despor Dis 1988;138:518-23.

23 Burrows B, Lebowitz MD, Camilli AE, Knudson RJ. Longitudinal changes in forced expiratory volume in one second tudinal changes in forced expiratory volume in one second in adults: methodologic considerations and findings in

24 Ohman JL, Sparrow D, MacDonald MR. New onset wheezing in an older male population: evidence of allergen sensitization in a longitudinal study. $\mathcal{F}$ Allergy Clin Immunol 1993;91:752-7.

25 Gottlieb DJ, Sparrow D, O'Connor GT, Weiss ST. Skin test reactivity to common aeroallergens and decline of lung function: the Normative Aging Study. Am 7 Respir Crit Care Med 1996;153:561-6. 